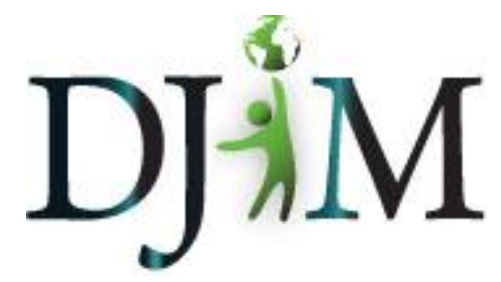

Volume 5 - Spring 2009

djim.management.dal.ca

\title{
Reference Analysis as an Aid in Collection Development: A Study of Master of Architecture Theses at Dalhousie University
}

\begin{abstract}
Librarians face difficult collection management decisions due to the proliferation of potential resources and the limited funding available to libraries. Reference analysis can act as a tool for selecting and de selecting materials because it provides insight into the materials that are selected by various user groups. This study analysed references in graduate architecture theses at Dalhousie University written between 2003 and 2006 to determine the format and age of materials used and the most frequently cited items. The study indicated that the average age of materials used was 18 years. It also showed that $65 \%$ of the items referenced were monographs, $17 \%$ were web-based materials and $10 \%$ were serials. This is contrary to other reference analyses, which found that journals are the most frequently used format. These findings suggest the need for further research into information literacy and interlibrary loan. To confirm this study additional reference analysis of Dalhousie architecture collections are necessary.
\end{abstract}

About the Author(s): The authors are currently second year Master of Library and Information Studies students in the School of Information Management at Dalhousie University. This paper was originally written for a Library and Information Studies course, Research Methods.

Kelly Dickinson previously completed a Bachelor of Arts at the University of New Brunswick in History and Political Science. She became interested in interdisciplinary research and academic librarianship while working in the Reference department at the Harriet Irving Library at UNB.

Regan Gunningham completed her Bachelor of Arts at the University of Regina. She is currently an intern at the Sexton Design and Technology Library which provides reference services to engineers, architects and planners. Her experience has led to an interest in improving library services through information literacy.

Bryanna Boyd earned a Bachelor of Commerce with a minor in Psychology at Carleton University. She is currently employed in the Cataloguing and Database Management 
departments at the Patrick Power Library at Saint Mary's University. Bryanna's work experience and research has developed her interest in online catalogues and collection access.

\section{Introduction}

With the ever-increasing number of books and journals in existence, libraries are challenged with deciding which books they will purchase and to which journals they will subscribe. They must contend with limited and sometimes decreasing funding, as well as limited physical space in which to house their collections. Inadequate funding may result in problems related to staffing, programming, facilities, and collection management (See Appendix) (American Library Association, 2006).

Citation analysis (See Appendix) is a component of bibliometrics (See Appendix) that has been studied for over eighty years (Gross \& Gross, 1927). It is a research tool designed to find patterns within scholarly research. This method provides an unobtrusive and non-reactive means for gathering data (Sylvia, 1998, p.22). A local reference analysis can provide librarians with statistics necessary to justify budgetary increases to improve core collections. 'In an age of spiraling journal costs and shrinking budgets, local citation analysis is one tool for enabling libraries to develop strong and cost-effective collections" (Rethlefsen, 2007, p. 265). Citation analysis is used as a tool for collection evaluation (Chambers \& Healey,1973; Williams \& Fletcher, 2006; Waugh \& Ruppel, 2004). Researchers study the citations that are used in scholarly works to determine trends that will impact library collections. Although 'the term citation analysis has been commonly used to describe this type of study, this really is, in essence, a 'reference analysis"' (Georgas \& Cullars, 2005, p. 499).

An examination of citation analysis research appears to indicate a lack of information written about the architecture discipline. Recent examples of citation analyses by Williams and Fletcher (2006) and Haycock (2004) indicate the usefulness of subject specific research. Williams and Fletcher found that academic libraries rely on faculty to assist in collection development but students have very little input into the process (2006). Graduate students are one of the primary user groups and they require research materials that do not always reflect the interests of faculty (Pancheshnikov, 2007, p. 675). Citation analyses of theses and dissertations provide library staff with a broader perspective of the demands made on their collections.

Journals are one of the most commonly used research tools (Pancheshnikov, 2007; Rethlefsen, 2007; Williams \& Fletcher, 2006). Citation analysis can be used to rank, evaluate and categorize journals based on their frequency of article citation. It can help identify areas of weakness within a collection (Rethlefsen, 2007, p. 264). In 1948 Bradford formulated an empirical law that is a standard in the field of bibliometrics to identify and rank resources based on their citation frequency. The Law states that: If scientific journals are arranged in order of decreasing productivity of articles on a given subject, they may be divided into a nucleus of periodicals more particularly devoted to the subject and several groups or zones containing the same numbers of articles as the nucleus, when the numbers of periodicals in the nucleus and succeeding zones will be as $1: n: n^{2}: \ldots$ (Brookes, 1969, p. 953). 
Bradford's Law (See Appendix) is particularly effective when all materials from a defined timeframe and subject are included. Libraries can implement Bradford's Law when making collections management decisions.

Data collected from a reference analysis has repercussions beyond collection management. It provides insight into reference services and information literacy instruction (Georgas \& Cullars, 2005 p. 496). Bibliometric studies increase the knowledge of librarians who have no academic background to support their work. 'In the absence of highly expert subject specialists on a library staff, citation studies can be of considerable value in choosing serials and even monographs" (Broadus, 1977, p. 328).

Citation analysis is an effective tool but it has limitations. MacRoberts and MacRoberts (1989) stated that 'most authors simply did not cite the majority of their influences, and none cited all influences" (p. 343). Graduate students may include references even if a work is marginal or irrelevant to their theses (Sylvia, 1998, p. 22). In turn, students may not cite important research if it is not published in their native language or cannot be found locally (MacRoberts \& MacRoberts, 1989, p. 345; Sylvia, 1998, p. 22). Researchers must use caution when drawing conclusions and making recommendations based solely on citation analysis data. Broadus (1977) recommends using citation analysis in addition to considering in-house use, circulation, and interlibrary loans to determine the usefulness of items.

Reference analyses have been used as a collection development tool within the disciplines of engineering, linguistics, education, sciences and psychology (Williams \& Fletcher, 2006; Georgas \& Cullars, 2005; Haycock, 2004; LaBonte, 2005; Sylvia, 1998). Based on a survey of the available literature, it appears that no citation or reference analyses for the architecture discipline have been published, indicating that research within the field is necessary.

In 2006 a committee of three librarians were engaged to perform an external review of the services and resources at Dalhousie University's Sexton Design \& Technology Library. The committee consisted of librarians with expertise in engineering, architecture, and library management. The committee engaged in a review of library materials and interviews with faculty, staff, and students, and found that 'faculty and graduate students [at Sexton Library] revealed their view that the collection does not support advanced research, graduate work..." (Berger, Philipps, \& Presser, 2006, p. 3). The Canadian Architectural Certification Board reported in the accreditation review that the collection was below the expected standard (Berger, Philipps, \& Presser, 2006). The committee also identified gaps in the monograph collection.1

\section{Research Problem}

The purpose of this study is to analyse the references found within Master's theses written by architecture students at Dalhousie University during the period of 2003-2006. This paper will answer the following questions:

1) What materials are used by graduate architecture students? 
2) What is the age of the material cited in the theses?

3) What are the most frequently cited journals within Dalhousie architecture theses?

\section{Methods}

Master's theses of Dalhousie architecture students published between 2003 and 2006 were reviewed by three researchers. Data was collected using the ProQuest Dissertations \& Theses database. Researchers submitted a search query that limited records to:

- School location: Dalhousie

- Degree: M. Arch

- Date range: 2003-2006

This resulted in 165 theses to study; however, 1 thesis was scanned incorrectly by Proquest. The remaining 164 theses were available in a full-text PDF format. The researchers collected data from the lists of references that students included at the end of their theses but they did not count how many times each reference was cited within the document. The documents had not been scanned in an electronically-searchable format, and manual searching would have been excessively time-consuming and susceptible to human error. Researchers entered the bibliographic references into a Microsoft Access database. Citations that did not include the name of the author, publisher and date were excluded. Several entries for buildings and organizations were excluded because they did not include all three of the items stipulated above.

The database consisted of three tables. The first table included a unique number to identify each thesis, the author's name, the title of the thesis and the date it was published. The second table listed all of the bibliographic formats used by the Master's students. The third table was connected to the first two tables in order to retrieve the author of the thesis and the format of materials. This ensured that the researchers used consistent terms in their data entry. The fields in the third table included:

- Thesis from which the reference originated

- Format of material

- Title of the article

- Title of the serial or monograph

- Primary author 
- Date of publication

- Publisher

- Website

The format of the referenced material was analysed to determine the type of material used most frequently by the architecture graduate students. The publication dates of the material were analysed and averaged. To find the average publication date, records without dates and records from websites were excluded. The journal frequency data was grouped according to Bradford's Law. According to this law, journals were placed into three groups based on the frequency of references.

\section{Results}

\section{Format of Materials}

The data gathered from the 164 architecture theses consisted of 3956 collected references. The following are some of the key discoveries made regarding the format of materials:

- Monographs accounted for $65 \%$ of the references.

- Serials (print and electronic) accounted for $10 \%$ of the references.

- Web-based materials (websites, websites - government, websites - photo) accounted for $17 \%$ of the references.

- Based on a sampling of 406 of the websites that were referenced, $65 \%$ of them were active as of April 9, 2008.

. The remaining nine categories accounted for the final $18 \%$ of the references.

- The 'other' category consisted of items such as personal interviews, pamphlets, speeches, sound recordings and exhibition catalogues. These were classified as 'other' because there were too few items to constitute an entire format category.

A complete breakdown of the 15 formats used in the theses is found in Table 1.

\section{Age of Materials}

The publication dates of material cited range from 1525 to 2006. Table 2 shows that almost a quarter of the referenced items were published within the last six years. To determine the average age of published materials the researchers excluded references that did not contain a publication date or were from websites. The website material was excluded because the material is not contained within the library collection and the publication dates would have no impact on collection development. The mean publication date of the remaining references was 1990 and the median was 1995. 


\section{Journal Frequency}

The thesis citations contained 399 journal references from 185 journal titles. The top $6 \%$ of journals accounted for $33 \%$ of the total journal references. The journals were placed into three zones according to Bradford's Law. The number of journal references (399) was divided by 3 to determine how many references should be included in each zone ('Bibliometrics", n.d.). The first zone contained 11 journal titles and 134 references (See Table 3). The second zone contained 132 references in 48 journal titles (See Table 4) and the third zone had the remaining 126 journal titles and 133 references. The majority of the journals only received 1 citation.

\section{Table 3: Zone One Journals}

\begin{tabular}{lc} 
Title & Number of Articles \\
\hline Architectural Design & 22 \\
Journal of Architectural Education & 17 \\
Architectural Record & 16 \\
Architectural Review & 14 \\
a + u & 13 \\
Canadian Architect & 11 \\
Energy and Buildings & 10 \\
Progressive Architecture & 9 \\
El Croquis & 8 \\
Toronto Star & 7 \\
Architecture & 7
\end{tabular}

Table 4: Zone Two Journals

\begin{tabular}{|c|c|c|c|}
\hline Title & Number of Articles & Title & Number of Articles \\
\hline $\begin{array}{l}\text { Architects } \\
\text { Journal }\end{array}$ & 5 & Arkkitehti & 2 \\
\hline GA Document & 5 & $\begin{array}{l}\text { Australian } \\
\text { Geographical Studies }\end{array}$ & 2 \\
\hline Vancouver Sun & 5 & Azure & 2 \\
\hline Minnesota & 4 & $\begin{array}{l}\text { Building and } \\
\text { Environment }\end{array}$ & 2 \\
\hline ASHRAE & 4 & $\begin{array}{l}\text { Canadian Architecture } \\
\text { Magazine }\end{array}$ & 2 \\
\hline Cuidad Arquitectura & 4 & Chronicle Herald & 2 \\
\hline $\begin{array}{l}\text { Historical and } \\
\text { Archeology Society }\end{array}$ & 4 & Coast & 2 \\
\hline $\begin{array}{l}\text { Journal of } \\
\text { Environmental } \\
\text { Psychology }\end{array}$ & 4 & Daily News & 2 \\
\hline Montreal Star & 4 & Designing the World's & 2 \\
\hline
\end{tabular}




\begin{tabular}{|c|c|c|}
\hline & & Best \\
\hline Oppositions & 4 & Detail \\
\hline Planning & 4 & $\begin{array}{l}\text { Environment and } \\
\text { Behavior }\end{array}$ \\
\hline $\begin{array}{l}\text { Wood Science and } \\
\text { Technology }\end{array}$ & 4 & Fifth Column \\
\hline AIA & 3 & Globe and Mail \\
\hline Assemblage & 3 & In Chora \\
\hline Halifax Mail & 3 & $\begin{array}{l}\text { Landscape } \\
\text { Architecture }\end{array}$ \\
\hline LA Times & 3 & Living Architecture \\
\hline National Geographic & 3 & Macleans \\
\hline October & 3 & Modulus \\
\hline Perspecta & 3 & National Post \\
\hline Princeton Journal & 3 & On Site \\
\hline World Architecture & 3 & Place \\
\hline AA files & 2 & $\begin{array}{l}\text { Royal Institute of } \\
\text { British Architects }\end{array}$ \\
\hline Al Ahram weekly & 2 & Solar Energy \\
\hline $\begin{array}{l}\text { Annals of American } \\
\text { Academy of Political } \\
\text { and Social Science }\end{array}$ & 2 & Threshold \\
\hline
\end{tabular}

\section{Discussion}

\section{Formats of Materials}

Based on research literature, journals were expected to be the most commonly cited material format. Citation analyses of scientific materials found that journals typically represent $80 \%$ of the content cited. (Bowman 1990 and Devin \& Kellogg, 1990 as cited by LaBonte, 2005). The results of this architecture research do not reflect existing studies of scientific publications. This may be due to the nature of the architecture discipline. Although there is a need for technical skills and information, the architecture students referenced a broad range of materials that incorporate music, philosophy, politics, and other topics indirectly related to architecture. Architecture may be more closely aligned with social sciences or arts and humanities disciplines which rely less heavily on journals than their science counterparts (Kushkowski, Parsons, \& Wiese, 2003). The findings of this research show that monographs are the most frequently referenced and that just over $10 \%$ of the materials cited are journals. The data clearly indicates that a large percentage of an architecture library's budget should be spent on monographs. This finding corresponds with the Berger, Philipps, and Presser external review which recommended an increase to the monograph collection.

The increasing use of online resources may also impact library collections. After sampling the web-based references the researchers found that $35 \%$ were not accessible. This may be partially due to typographical errors made by students when creating the reference or when researchers entered the reference into the database. Some of the websites may also no longer 
be maintained by their owners. The use of stable and reliable websites might become more prevalent if libraries devoted resources to cataloguing and preserving web-based documents.

\section{Age of Materials}

The reference materials within this study were notably older than those in an engineering reference analysis conducted by Williams and Fletcher. Williams and Fletcher found that ' $50 \%$ of all materials cited were published within the last eight years" (2006), as compared to the findings of 13 years from this architecture study. This information emphasises that architecture is a unique discipline and that older materials still have a purpose. A librarian at Dalhousie's Sexton Library confirmed that architecture materials do not become dated and they retain their value over time. This is reflected in the current draft of their collection policy $(\mathrm{H}$. Powell, personal communication, February 12, 2008).

The average publication date of materials was 1990. Determining the age of materials can be a useful tool when de-selecting or deciding if materials should be sent to off-site storage or archival facilities. However, de-selecting architecture materials based on the age of publication is not a valid method. The Sexton Library only de-selects materials that are in poor condition or those superseded by newer editions (H. Powell, personalcommunication, February 12, 2008).

\section{Frequency of Journals}

Determining the frequency of journals can assist library staff in making collection development decisions. Dividing the referenced journals into three zones according to Bradford's Law can assist in the decision-making process. Journals in zone one have been identified by the graduate students as key resources and it is essential that students can access these items. The Sexton Library owns all of the serials in the first zone.

Journals listed in zone three are the items that are infrequently cited. If a library faces budgetary cuts, the journals within zone three may have the potential for de-selection. If items are readily available through document delivery and can be acquired in a timely manner, the library may not need to renew these subscriptions. Document delivery availability and journal citation frequency should not be used as the sole criteria for de-selecting materials. Details such as price, the specificity of a topic, the publication frequency, and in-library use are all to be considered when making de-selection decisions.

\section{Conclusion and Further research}

A reference analysis is an unobtrusive method of gathering data to assist in collection development. The results of the analysis will help staff gain further insight into and understanding of core resources and the type of multidisciplinary sources required by graduate architecture students. This analysis found that monographs are more frequently used than journals by architecture students, suggesting architecture research is more closely aligned with arts and humanities rather than pure sciences. Similarly, the age of materials used by architecture students was older than materials in other reference analyses. The research also identified the most frequently and infrequently used journals. These findings may assist 
librarians facing limited budgets when making selection and de-selection decisions. A reference analysis can be a useful collection management tool if its limitations are recognized. Based on research observations, other areas must be studied to develop a comprehensive overview of library services and resources. Suggested areas for further research include information literacy, the use of interlibrary loan, and reference analyses from similar architecture graduate programs.

Based on the researchers' findings that architecture students used older materials that were primarily monographs, it would be useful to study their research habits. A study could determine if students are using all available tools to search for articles, maps and images rather than relying on the local catalogue which principally includes monographs. Additionally, the researchers discovered that many of the citations were poorly documented. Library staff could examine how best to educate students about citation styles, as it is an important professional skill. The fact that $17 \%$ of the resources used were web-based also has implications for information literacy services offered by the library. Research should be done to determine if students evaluate their web-based resources for validity and authority.

Additional research should be conducted into the use of services such as interlibrary loan and document delivery. Before making collection management decisions, library staff should investigate the format and age of materials borrowed through other libraries. If their research indicates a significant gap in the collection, staff can determine if purchasing resources is more cost-efficient than borrowing from other libraries.

The findings of this research indicate that the collection needs of architecture students are unique. Monographs were used for the majority of the architecture references in this analysis. This strongly contrasts with the studies in the fields of arts and sciences, as found by LaBonte (2005) and Kushkowski, Parsons and Wiese (2003). Further research needs to be conducted to determine if this reference analysis is an accurate representation of similar architecture collections.

\section{References}

American Library Association. (2006, December). Avoiding and handling budget cuts. Retrieved February 1, 2008, from http://www.ala.org/ala/issues/handlingbudgetcuts.htm

Berger, M., Philipps, J., \& Presser, C. (2006). External review : Dalhousie University Libraries, Sexton Design \& Technology Library.

Bibliometrics. (n.d.). Retrieved April 4, 2008, from

http://www.ischool.utexas.edu/ palmquis/courses/biblio.html [11]

Bibliometrics. (1993). In Oxford English Dictionary. Retrieved February 4, 2008, from http://dictionary.oed.com/cgi/entry/00291736?single=1\&querytype=word\&queryword=bibliomet rics\&first $=1 \&$ maxtoshow $=10$ 
Bradford's Law. (2007). In Online Dictionary for Library and Information Science. Retrieved April 4, 2008, from http://lu.com/odlis/odlisb.cfm

Broadus, R. N. (1977). Citation analysis \& library collection building. Advances in Librarianship 7, 300-335.

Brookes, B.C. (1969). Bradford's Law and the Bibliography of Science. Nature, 224, 953-956.

Chambers, G., \& Healey, J. (1973). Journal citations in master's theses: One measurement of a journal collection. Journal of the American Society for Information Science, 24(5), 397-401.

Citation analysis. (2007). In Online Dictionary for Library and Information Science. Retrieved February 4, 2008, from http://lu.com/odlis/index.cfm

Collection management. (2007). In Online Dictionary for Library and Information Science. Retrieved February 4, 2008, from http://lu.com/odlis/index.cfm

Georgas, H., \& Cullars, J. (2005). A citation study of the characteristics of the linguistics literature. College and Research Libraries, 66(6), 496-515.

Gross, P. L. K., \& Gross, E. M. (1927). College libraries and chemical education. Science, 66(1713), 385-389.

Haycock, L. (2004). Citation analysis of education dissertations for collection development. Library Resources \& Technical Services, 48(2), 102-107.

Kushkowski, J., Parsons, K. \& Wiese, W. (2003). Master's and doctoral thesis citations: Analysis and trends of a longitudinal study. Libraries and the Academy, 3 (3),459-479.

LaBonte, K. (Summer 2005). Citation analysis: a method for collection development for a rapidly developing field. Issues on Science and Technology Librarianship.

MacRoberts, M., \& MacRoberts, B. (1989). Problems of citation analysis: A critica review. Journal of the American Society for Information Science, 40(5), 342.

Nisonger, T.E. (1992). Collection evaluation in academic libraries: A literature and annotated bibliography. Englewood, CO : Libraries Unlimited

Pancheshnikov, Y. (2007). A comparison of literature citations in faculty publications and student theses as indicators of collection use and a background for collection management at a university library. The Journal of Academic Librarianship,33(6), 674-684.

Rethlefsen, M. (2007). Citation analysis of Minnesota department of health official publications and journal articles: A needs assessment for the RN Barr library.

Journal of the Medical Library Association, 95(3) doi:10.3163/1536-5050.95.3.260 
Sylvia, M. (1998). Citation analysis as an unobtrusive method for journal collection evaluation using psychology student research bibliographies, Collection Building, 17(1), 20-28.

Waugh, C. K., \& Ruppel, M. (2004). Citation analysis of dissertation, thesis, and research paper references in workforce education and development. The Journal of Academic Librarianship, 30(4), 276-284.

Williams, V. K., \& Fletcher, C. L. (2006, Winter). Materials used by master's students in engineering and implications for collection development: A citation analysis. Issues in Science and Technology Librarianship.

\section{Appendix}

\section{Definition of Terms}

\section{Bibliometrics}

The branch of library science concerned with the application of mathematical and statistical analysis to bibliography; the statistical analysis of books, articles, or other publications ('Bibliometrics", 1993).

\section{Bradford's Law}

The bibliometric principle that a disproportionate share of the significant research results on a given subject are published in a relatively small number of the scholarly journals in the field, a pattern of exponentially diminishing returns ('Bradford's Law", 2007).

Citation analysis

An analysis of references in and citations to documents such as books and articles (Nisonger, 1992).

A bibliometric technique in which works cited in publications are examined to determine patterns of scholarly communication, for example, the comparative importance of books versus journals, or of current versus retrospective sources, in one or more academic disciplines. The citations in student research papers, theses, and dissertations are also examined by librarians for purposes of collection evaluation and development ('Citation analysis", 2007).

Collection Management

The application of quantitative techniques, such as statistical and cost-benefit analysis, to the process of collection development, usually limited to large libraries and library systems. In a more general sense, the activity of planning and supervising the growth and preservation of a library's collections based on an assessment of existing strengths and weaknesses and an estimate of future needs ('Collection Management", 2007). 